\title{
Books in Tolerable Supply: College Libraries in North Carolina from 1795 to the Civil War
}

\author{
Patrick M. Valentine*
}

The historical role of college libraries has seldom been investigated on a regional or state level in the United States, but such studies are valuable in explaining the cultural infrastructure of education and print culture. State and regional studies also set the context for further research on individual libraries and colleges as well as histories on a larger level. This work examines how college libraries developed in North Carolina from 1800 to 1860 and illustrates the growth and ambience of education and print culture during a formative period of the antebellum South.

\section{A "professor in a College who is without books in tolerable supply, is analogous to the creation of nobility which for want of estate is obliged to live in rags."}

\author{
Joseph Caldwell, Letter, 19 February $1824^{1}$
}

\begin{abstract}
A number of southern colleges and universities trace their founding back to pre-Civil War times, yet historians have rarely studied their libraries. The scope, size and stability of libraries was limited in the early United States but grew during the decades preceding the Civil War. College libraries often had a dual role, serving both the college and the local community, yet curriculums and community interest were restricted. Nevertheless, some educators and students appreciated their worth and worked for library expansion. Benedict Anderson has argued convincingly that print culture had an important role in the formation of imagined national communities while Michael O’Brien has shown how the South was both regionally distinct and also part of a national, indeed international, intellectual community. ${ }^{2}$ What have been missing are studies of library development and infrastructure in the South, set within the context of Southern history and college life. This study will shed light on the role and status of libraries and education in general as well as the place of print in the antebellum South and early Republic by focusing on North Carolina. ${ }^{3}$
\end{abstract}

Most southern colleges saw their role as educating an elite of planters and lawyers. Smaller denominational colleges looked towards educating ministers, some teachers, and local planters. The students were young males pursuing a classical curriculum, often with reluctance. Discipline was a major problem. Course work generally emphasized memorization and outside reading was not encouraged. Professors, as elsewhere in the United States, were minimally-paid lecturers with scant interest in research or publishing. Southern education was not aimed at practical skills or interests beyond rhetoric, ministry, and teaching. Even within this cultural sphere, many observers of antebellum America considered North Carolina a backward state with little ambition and less education, a southern Rip Van Winkle. Nationally, this was a period of dynamic political and commercial change, but North Carolina in the early decades remained a largely rural and semi-subsistence economy. The state experienced only limited growth and urbanization even by $1860 .{ }^{4}$

What became North Carolina's largest library had its beginnings in 1795 with the University of North Carolina at Chapel Hill, North Carolina's first college and the first public university to open in the nation. ${ }^{5}$ The University, like later colleges in North Carolina and most of the South, was set in a rural area. Chapel Hill remained a village until well after the Civil War. Town life in the South, shackled with slavery and largely self-sufficient small farming or stable agribusiness, demonstrated modest signs of growth compared to northern towns and cities and provided little stimulus for the growth of college libraries. ${ }^{6}$ North Carolina had at the time only a few libraries, small private collections of schoolmasters, lawyers, clergymen, and planters.?

One of the University's first actions was to start a library with \$200 and whatever donations could be gleaned. The collection soon counted some 330 volumes but most were gifts and barely grew thereafter. "We find much difficulty in procuring books," admitted one professor. As a scholar-librarian in South Carolina later commented, "Nothing but the highest motives, or the most stringent necessity, could induce a man who knows and loves books, to make the sacrifice of parting with his [personal] library." The lack of suitable library books was such that students wrote home for standards like histories of Rome or copies of Thomas Paine. The largest library increase at the University came when its president, Joseph Caldwell, went on a book-buying trip to Europe in 1824. He acquired 979 books for the library - including copies of the Bible in forty-eight different languages. ${ }^{8}$ Caldwell, while an advocate of popular education, also imbued the University with a proper Princeton classical curriculum.

Book selection was difficult as professors often based acquisition decisions on very inadequate announcements in estate catalogs and newspaper advertisements. In addition, most of the university books were out-dated and in poor condition. One contemporary observed of the library that "...on its shelves are many ancient books of great value, but vacant spaces plead piteously for new books in all the departments of literature and science." 9 No college in North Carolina charged student fees for libraries, unlike Virginia institutions like Roanoke College and the Virginia Military Institution. ${ }^{10}$

A second large accretion came in 1858 when the University of North Carolina bought the books left by its most prominent professor, geologist Elisha Mitchell - only to discover that many of the books in Mitchell's estate already belonged to the school. ${ }^{11}$

* Assistant Professor, Library Science and Instructional Technology, East Carolina University, Greenville, NC 
This was during the administration of David L. Swain, the University's president from 1836 through the Civil War, who bought few if any other books for the library. In contrast, South Carolina, with a view towards cultural independence, during this same period spent some $\$ 3,000$ a year on books. Swain, a former governor who finished only three years of college at Chapel Hill, supposedly sometimes kept the library books in an attic. Swain moved the library to a new building, Smith Hall, in 1854 more to justify its construction than to provide a suitable library. Smith Hall was primarily used for dances, with books lined around the walls and a reading room in the basement. ${ }^{12}$ Libraries, here as elsewhere in the United States at this time, were modest collections of books, plus perhaps a few periodicals, not grand edifices with determined acquisition programs.

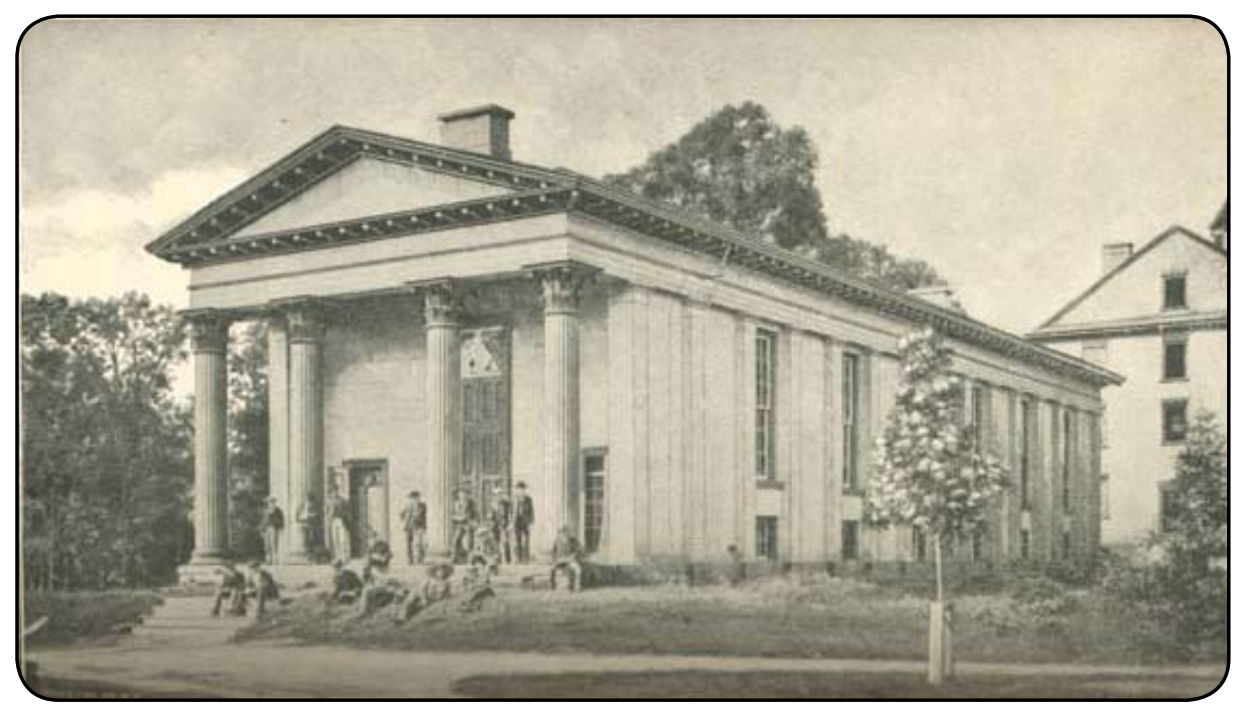

Figure 1. Smith Hall was built in $\mathbf{1 8 5 1}$ as the University of North Carolina library but was used mainly for dances. This idealized image comes from Charles Lee Smith, The History of Education in North Carolina (Washington: Government Printing Office, 1888), 74a. University of North Carolina, “Documenting the American South.” http://docsouth.unc. edu/true/smith/ill7.html

The libraries of the two debating societies at the University in many ways over-shadowed the official library. Their libraries recall those of the medieval student halls. Since debating was excellent training for lawyers and almost anyone in a litigious society, these societies dominated much of campus life. Students were often more highly engaged in these society activities than in the lectures and rote memorization of official studies. Their debates and presentations were lively and required contemporary books and magazines. Student libraries therefore often engendered more interest than did the official collections, not just in the South but in many American colleges. ${ }^{13}$ In 1832 a student at the University of North Carolina boasted that the Philanthropic Society "is full of books \& we have not room for the continual additions made to it" while twenty years later students complained that "the present limits of our Libraries shame us." "The Davidson College catalogue in 1843 claimed that "the Literary Societies of the students are known to be under good regulations, and [are] highly favorable to the promotion of intellectual improvement." ${ }^{15}$

The Philanthropic Society at Chapel Hill began buying books as early as 1797 and had a hundred titles by 1803. Student societies typically increased their library collections by extending honorary membership to notable men who were expected to donate a book in return. The Society appointed student Library Supervisors who reported on library conditions in writing. These reports soon developed into inventories that, by 1820, were arranged by subject and short title. Carolina's Dialectic Society in 1821 printed a short-title catalog of 1,673 books arranged in alphabetical order and sorted by subject. The Phi's in turn published a slightly more elaborate catalog of their 1,473 titles the following year. ${ }^{16}$ Davidson's Philanthropic Society, for its part, produced its first catalog in 1852 with books arranged by titles but not subject. Alcove and shelf locations were listed however. ${ }^{17}$ These student inventories demonstrated a pride and sense of competition and were far in advance of any catalogs of southern college libraries.

Little is known about how academic libraries organized their books. It does not appear that the Philanthropic Society books, for instance, were actually arranged by subject in the 1820s. The Euzelian Society of Wake Forest arranged its books "according to appearance” and boasted of its Latin Bible printed in Germany in 1566. The University of North Carolina library in 1857 noted how many of its books were folios, quartos, octavos, or little duodecimos, which suggests the books were arranged by size. ${ }^{18}$ There does not seem to be any evidence that books were chained to shelves or lecterns as in many medieval and Renaissance libraries. ${ }^{19}$ Southern colleges and their libraries were not research institutions although the German model was certainly not unknown. ${ }^{20}$

Librarian Ashbel Green Brown reported in 1850 that the University had 3,501 books, the Dialectic Society had 4,535 and the Philanthropic Society 4,311, quite a jump from the 300 or so books in 1800 . The society libraries, however, often selected identical titles - "only more handsomely bound, if possible" - so it cannot be assumed that students had access to some 10,000 or 11,000 different volumes. The Dialectic library was open two hours a week while the University's stayed "open five times a week, an hour at a time." "All residents on the Hill who seem to be proper persons to have books" were allowed to use the University library unlike the society libraries. Records, however, clearly show that the latter circulated more books. ${ }^{21}$

Although the University library was theoretically open to all, and therefore something of a "public" or community library, its collection was very academic and dated, while the student libraries had more lively reading matter but restricted its use to their own members and faculty. This situation was probably true for all the colleges mentioned here and most college libraries everywhere in the States. ${ }^{22}$ The location of college libraries in very small towns like Chapel Hill, Wake Forest and Davidson, moreover, accentuated their isolation and attenuated public usefulness outside of academia.

Students ran the debating libraries, but who manned college libraries? Little is recorded about them. That is because there were few if any persons whose chief duty in life was to operate the library. There were libraries but no librarians. ${ }^{23}$ One of the initial faculty members at the University of North Carolina, Hugh Williamson, apparently organized its first set of library books 
in 1795. Signer of the Constitution and a prominent scientist, historian, and physician, Dr. Williamson might be considered the most distinguished nineteenth-century North Carolina librarian - but that would be stretching an afternoon's duty too far. In any case, Williamson hardly stayed at the University after its founding. ${ }^{24}$

Starting sometime after Williamson's departure, graduate-tutors served as librarian as part of their duties. In 1834 Thomas Samuel Ashe, later to be a Congressman, was assured that the duties "are light and would leave a great portion of time entirely" at his command, but he declined anyway. The librarians received one-half of the overdue fines collected, a figure that was stabilized at $\$ 100$ a year in 1838 after which the Senior Tutor was confirmed as librarian. The first tutorlibrarian mentioned by the University's historian was Joseph Hubbard Saunders in 1824. Saunders later became an Episcopal priest but died young in Florida. His most noteworthy successor was William Hayes Owen who served seven "tedious and toilsome" years from 1836 to 1843 and then became a professor of ancient languages at Wake Forest College. ${ }^{25}$ The already mentioned Ashbel Green Brown was librarian for the following twelve years. A tutor of ancient languages, he impressed one visitor to the campus with his "retentive memory and discriminating mind.” But a close acquaintance instead said Brown "was a serious man, devoid of humor, ... of abnormal nervous sensibility” who had to resign while only in his forties. ${ }^{26}$

Reverend John Armstrong, Professor of Ancient Languages, served as the first librarian at Wake Forest College, 1835 to 1837 , and was succeeded by the tutor, Reverend H. A. Wilcox. Wake Forest, a Baptist institution, gave the library books to its student societies in 1844. J. Thomas Raynor, Euzelian, and William Jones, Philomathesian, were the first student librarians while Professor Owen, the former University tutor, and his sisters made significant benefactions to both society libraries. By 1857 Wake's Philomathesian Society had some 2,400 volumes and the Euzelian Society owned 3,386. "Great crowds" would gather when a new shipment of library books arrived. When "the beautiful new volumes [were] laid out," the students "could not restrain their expressions of admiration, while those nearest would not make way for those in the rear, some of whom had to wait another day before getting to see and handle the volumes." Students readily filled library subscriptions for two hundred to three hundred dollars. The Wake Forest societies would even borrow substantial sums rather than wait to fulfill their book orders. "Not only were many volumes procured in this way, but most of them were readable; ... very few were dull theological treatises." ${ }^{27}$ Again, this demonstrates the relative popularity of the debating libraries while also showing that students were not numb to the charms of print culture.

What evolved into Duke University started in Randolph County in 1838 as Union Institute. Its founders, serious Methodists, complained of the "dissipation" current at the University of North Carolina. Union became North Carolina's Normal College in 1851 - a training school for teachers - and then changed its name to Trinity College five years later. Union's Columbian Literary Society had thirty-two books in 1849 and the rival Hesperian Society had amassed some 500 eight years later. While the official college library wilted without new books, Normal Institute matched donations given to the society libraries. The student societies bought books from dealers in Salisbury, Greensboro, and Raleigh as well as in the North. By the time the Civil War broke out, each Trinity debating society had 2,200 uncataloged volumes while the college library only possessed 650 books - mostly reference works. Lemuel Johnson, professor of mathematics and college treasurer, became the first official librarian in 1864, but Trinity later returned to selecting a different student as librarian almost every year. ${ }^{28}$

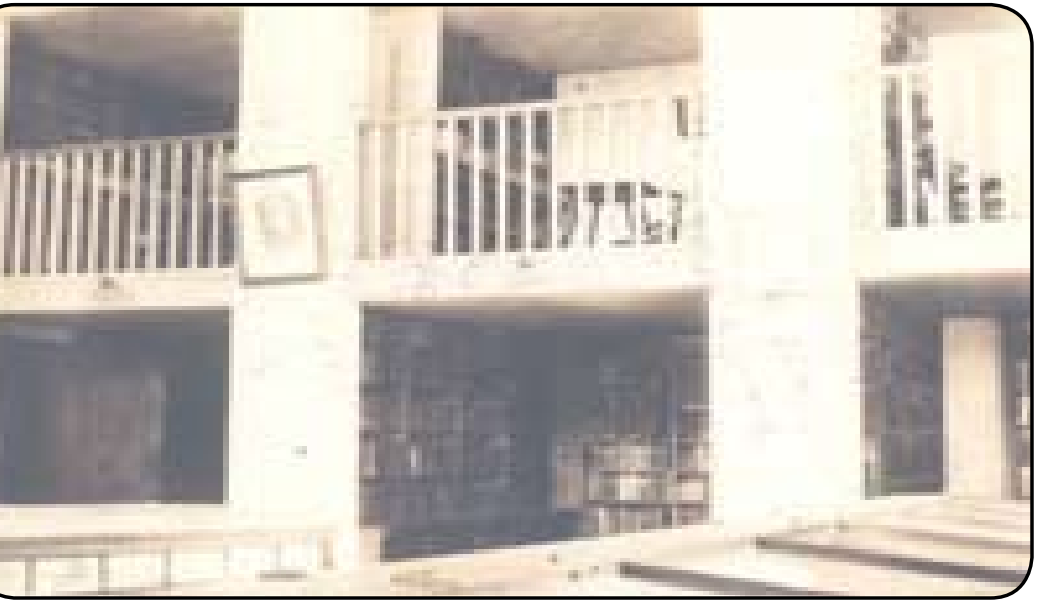

Figure 2: In 1860 Davidson moved its library into the new and very impressive Chambers Hall designed by Alexander Jackson Davis of New York. Date of picture unknown. Courtesy of the Davidson College archives.
Davidson, a Presbyterian college that opened north of Charlotte in 1837, had fewer than 224 different titles in 1841, all of them donated; its two debating societies had another 700 . The donations included sermons and histories, science texts, biographies of Napoleon and Lafayette, textbooks of Latin and Greek, and belle lettres of Shakespeare, Burns and Scott. The most interesting gift was a rare, complete set of the Enlightenment classic, Diderot's thirty-five volume Encyclopédie. After the historian William H. Foote gave money as well as books to the library, Davidson bought the Encyclopaedia Metropolitana, twenty-six volumes, and the Encyclopaedia Britannica, also twenty-six volumes. President Drury Lacy wrote to his Trustees in 1856, "If the Board could realize how refreshing and how animating these books have been, and are to us who, by our seclusion, are cut off from all access to Libraries, they would surely contribute to our enjoyment and usefulness by regular additions to our meager and ill-selected Library." This pathetic letter testifies to the poor quality of the library collection. The Davidson faculty honestly commented on one donation, some of the books "are worthy of a place on our shelves [only] because they serve to fill them." Professor Elijah Frink Rockwell, a graduate of Yale University, called in 1851 for a larger library: "Textbooks are not sufficient, we need the accumulated wisdom of all ages and all countries." On the other hand, the student societies at Davidson eagerly discussed and recorded their own selections and expenditures. "Everything about their libraries was a trouble the societies willingly undertook." ${ }^{29}$

Reputedly the wealthiest college south of Princeton before the Civil War, Davidson had about 8,000 books for its ninety enrollees in 1857. Two years later some students burned books by Voltaire, Rousseau, and Thomas Paine - possibly a worse fate for books than at Chapel Hill, where "the tall tomes of St. 
Augustine" were especially "efficacious in slaughtering" mice that infested the halls. ${ }^{30}$ Perhaps inspired by Davidson's example, the Philomathesian Society at Wake Forest banned Paine's theological works. Philomathesians also apparently removed Boccaccio's Decameron while the Euzelians at Wake burned their copy. Paine's atheism had long inspired North Carolina rebuttals, but the tense years leading up to the Civil War saw the growth of a prickly and defensive Southern mentality of which book burning may be another sign. ${ }^{31}$ A side consequence of this attitude, along with the parsimony that was a constant in Southern college life, was that college trustees made little effort to improve these "meager and ill-selected" collections other than by buying encyclopedias. And that encyclopedias could be considered important acquisitions at such a wealthy institution as Davidson indicates much about the situation of college libraries. ${ }^{32}$

All these colleges were for men only despite the fact, as Carolina historians long ago acknowledged, "girls displayed considerably more ambition for knowledge of books.”33 Salem Female Academy was perhaps the most noted, and certainly longest lived, advanced school for women. Starting shortly after the turn of the century, it had fifty books in 1807 (kept in a closet at Salem Tavern) and 1,800 volumes by 1857 . This would have been a very strong collection for such a small school and reflected the Academy's high reputation and serious - if restricted - curriculum. ${ }^{34}$ Most small colleges, male and female, were established and sponsored by denominations but almost always insisted they were non-sectarian. ${ }^{35}$ Probably all these colleges had some complement of books set aside as a "library" but southern colleges were loath to publish particulars. ${ }^{36}$

Other small schools included Western Carolina Male Academy, which neglected to declare how many books it had when asked in 1857, and the Chowan Female Collegiate Institute which demurely said it had "a small select library, and is well supplied with periodicals from various parts of the Union." ${ }^{37}$ Louisburg, chartered in 1787, reported a slow but real growth in its collection over the next half century. ${ }^{38}$ Transient colleges are not included here because of the lack of information, while others now called colleges, like Salem and Louisburg, were more academies than colleges. ${ }^{39}$ Establishing a college and building a library were not easy accomplishments even in the relatively prosperous 1850s. ${ }^{40}$ The South, as Michael O’Brien has convincingly shown, was not interested in professional scholars or their institutional underpinning. ${ }^{41}$ Even Harvard thought undergraduates needed access to only 500 books without special permission. ${ }^{42}$ Therefore it is not surprising that college libraries did not thrive.

Statistics are not very revealing for North Carolina or its neighboring states but do back up this bleak if truthful view of

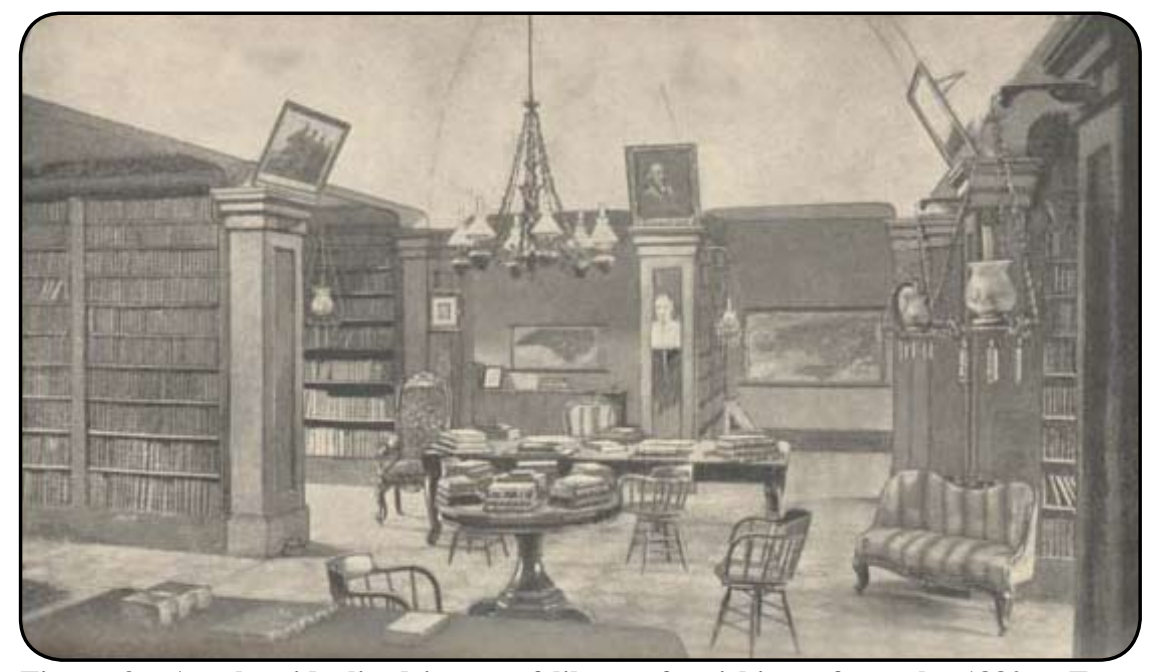

Figure 3: Another idealized image of library furnishings, from the 1880s. From Charles Lee Smith, The History of Education in North Carolina (Washington: Government Printing Office, 1888), 52a. University of North Carolina, "Documenting the American South.” http://docsouth.unc.edu/true/smith/ill7.html

Southern College Libraries in 1850, 1857 and $1860^{45}$

\begin{tabular}{|c|c|c|c|c|c|c|c|c|}
\hline \multirow[t]{2}{*}{ States } & \multicolumn{2}{|c|}{1850 Census } & \multicolumn{2}{|c|}{1850 Jewett Survey } & \multicolumn{2}{|c|}{1857 Rees Survey } & \multicolumn{2}{|c|}{1860 Census } \\
\hline & Libraries & Volumes & Libraries & Volumes & Libraries & Volumes & Libraries & Volumes \\
\hline Alabama & 5 & 7,500 & 4 & 13,000 & 8 & 24,729 & 3 & 14,000 \\
\hline Georgia & 9 & 21,500 & 5 & 15,637 & 7 & 28,613 & 11 & 17,800 \\
\hline Kentucky & 11 & 33,225 & 10 & 37,150 & 24 & 47,485 & 4 & 9,400 \\
\hline Louisiana & 3 & 5,000 & 4 & 13,000 & 18 & 24,100 & 1 & 3,000 \\
\hline Mississippi & 4 & 10,093 & 3 & 5,189 & 14 & 12,740 & 1 & 5,000 \\
\hline North Carolina & 5 & 21,593 & 3 & 9,401 & 10 & 12,501 & 7 & 15,100 \\
\hline South Carolina & 7 & 30,964 & 2 & 19,000 & 15 & 56,350 & 4 & 43,700 \\
\hline Tennessee & 5 & 9,925 & 9 & 20,844 & 25 & 51,122 & 16 & 34,600 \\
\hline Texas & 1 & 100 & 1 & 300 & 23 & 1,350 & 6 & 7,300 \\
\hline Virginia & 14 & 50,856 & 9 & 45,790 & 16 & 82,887 & 18 & 67,150 \\
\hline Totals & 64 & 190,756 & 50 & 179,311 & 160 & 341,877 & 71 & 217,050 \\
\hline
\end{tabular}


them is stressed here. ${ }^{43}$ With the onset of the Civil War, southern intellectuals would disclaim passionately about the superiority of their culture and cultural institutions but in fact had done little, as we have shown here, to build and strengthen college libraries. ${ }^{44}$

College libraries in North Carolina were assemblages of books and magazines with minimal organization or cataloging. They were not imaginary but neither were they substantial, and in this were not too dissimilar from college libraries in the North or, for that matter, in France or Britain. ${ }^{46}$ Insignificant libraries hardly fed the meager Southern intellectual establishment, and it is noticeable that no leading literary works or magazines originated from Southern colleges. Library equipment and furnishings were almost non-existent, while collection development, reference, and research services all waited for the future. ${ }^{47}$ Near the end of our period, a student at the University of North Carolina concluded, "If Rip Van Winkle wants ... libraries which shall command the attention of good talents, he must wake up." ${ }^{48}$

In 1800 North Carolina had only one college library, with a couple hundred mostly cast-off books, and in 1860 it still had only seven colleges with 15,000 books. The increasing presence and accessibility of print materials were noteworthy but further development was cut short by the Civil War and Reconstruction. ${ }^{49}$ The limited attention paid to college libraries reinforces the dominant view of the South as an area of "low investment in education and other social amenities." 50 One might say that Southern disinterest in intellectual and literary matters resulted in a lack of social structures such as libraries reflective of such inclinations, and that the lack of libraries in turn reinforced the non-intellectual cast of mind. ${ }^{51}$ Although the antebellum South tried, it never produced an adequate library infrastructure to support much more than an imaginary intellectual community. By 1860 North Carolina and Southern colleges had books in tolerable but not ample supply.

\section{References}

${ }^{1}$ Quoted in Fisk P. Brewer, The Library of the University of North Carolina (North Carolina?: s.n., 1870?).

${ }^{2}$ Benedict Anderson, Imagined Communities (London: Verso, 1983), 35-36; Michael O’Brien, Conjectures of Order: Intellectual Life and the American South, 1810-1860, 2 vols. (Chapel Hill: University of North Carolina, 2004).

${ }^{3}$ Wayne Wiegand has complained repeatedly over the lack of contextual library histories: "Tunnel Vision and Blind Spots: What the past tells us about the present; reflections on the twentiethcentury history of American librarianship,” Library Quarterly, 69/1 (January 1999): 1-32; “American Library Literature, 19471997: Theoretical Perspectives?” Libraries \& Culture 35/1 (Winter 2000): 4-34; “The Rich Potential of American Public School Library History: Research Needs and Opportunities for Historians of Education and Librarianship," Libraries \& the Cultural Record 42/1 (2007); see also Robert Darnton, “'What Is the History of Books?’ Revisited,” Modern Intellectual History 4/3 (2007): 495508. On college libraries see Benjamin Edward Powell, "The Development of Libraries in Southern State Universities to 1920” (Ph.D. diss., University of Chicago, 1946); Howard Clayton, “The American College Library: 1800-1860,” Journal of Library History 3 (1968): 120-37; Joe W. Kraus, “The Book Collections of Early American College Libraries,” Library Quarterly 43 (1973): 142-59; Orvin Lee Shiflett, Origins of American Academic
Librarianship (Norwood, NJ: Ablex Publishing, 1981); Sharon Gray Weiner, "The History of Academic Libraries in the United States: A Review of the Literature," Library Philosophy and Practice 7 (2005): 1-12 [available only electronically at http:// libr.unl.edu:2000/LPP/weiner.htm]; and Patrick M. Valentine, "Small Select Library or Miserable Excuse: Antebellum College Libraries in the Southeast," Southeastern Librarian (Summer 2006): 6-11. For broader discussions, see Ronald J. Zboray and Mary Saracino Zboray, A Handbook for the Study of Book History in the United States (Washington, D.C.: Library of Congress, 2000); A History of the Book in America, eds., Hugh Amory \& David D. Hall (Cambridge: American Antiquarian Society/ Cambridge University Press, 2000-2007), vols. 1 and 3; David Finkelstein and Alistair McCleery, An Introduction to Book History (New York: Routledge, 2005); and Michael H. Harris, History of Libraries in the Western World, $4^{\text {th }}$ ed. (Metuchen, NJ: Scarecrow Press, 1995).

${ }^{4}$ Recent explorations of these themes include Milton Ready, The Tar Heel State: A History of North Carolina (Columbia: University of South Carolina Press, 2005); Sean Wilentz, The Rise of American Democracy: Jefferson to Lincoln (New York: Norton, 2005); Christopher Clark, Social Change in America: From the Revolution Through the Civil War (Chicago: Ivan R. Dee, 2006); John R. Thelin, A History of American Higher Education (Baltimore: John Hopkins Press, 2004); Kim Tolley and Nancy Beadie, "Socioeconomic Incentives to Teach in New York and North Carolina: Toward a More Complex Model of Teacher Labor Markets, 1800-1850,” History of Education Quarterly 46 (2006): 36-72; and Michael J. Paulus, "Beyond 'Pabulum for the Undergraduates': The Development of the Princeton Theological Seminary Library in the Nineteenth Century," Libraries \& the Cultural Record 42/3 (Summer 2007): 231-267. The expansion of communications during this period is best examined in William S. Powell, North Carolina Through Four Centuries (Chapel Hill: University of North Carolina Press, 1989); Ronald J. Zboray, A Fictive People: Antebellum Economic Development and the American Reading Public (New York: Oxford University Press, 1993); and D. W. Meinig, The Shaping of America, 4 vols. (New Haven: Yale University Press, 1986-2006), v. 2.

${ }^{5}$ William D. Snider, Light on the Hill: A History of the University of North Carolina at Chapel Hill (Chapel Hill: University of North Carolina Press, 1992); and William S. Powell, Higher Education in North Carolina (Raleigh: State Department of Archives and History, 1970). Chapel Hill was a small village thirty miles from the state capital, Raleigh, which itself had less than 700 people in 1800 and less than 5,000 in 1860. Neither of North Carolina's largest towns, New Bern (2,674 in 1800, 5,432 in 1860) and Wilmington (1,689 in 1800, 9,552 in 1860), had colleges. The University of North Carolina remained little known in the North. See Francis L. Hawks to David L. Swain, January 3, 1860, cited in O’Brien, Conjectures of Order, 44.

${ }^{6}$ Clark, Social Change in America, 202-206; Stuart M. Blumin, "When Villages Become Towns: The Historical Contexts of Town Formation," and Blaine A. Brownell, "The Idea of the City in the American South," The Pursuit of Urban History, ed. Derek Fraser \& Anthony Sutcliffe (London: Edward Arnold, 1983), 5468 and 138-150. Higher education, although a prize, was hardly a necessity even in the commercial South. Christopher Morris, Becoming Southern: The evolution of a way of life, Warren County and Vicksburg, Mississippi, 1770-1860 (New York: Oxford University Press, 1995), 36-41; Patrick M. Valentine, The Rise of a Southern Town: Wilson, North Carolina, 1849-1920 (Baltimore: Gateway Press, 2002), 10, 20-23; and Frank K. Byrne, Becoming 
Bourgeois: Merchant culture in the South, 1820-1865 (Lexington: University Press of Kentucky, 2006). Compare the situation in Charlottesville, home of the University of Virginia, which showed greater signs of commercial life and development according to John D. Majewski, A House Dividing: Economic development in Pennsylvania and Virginia before the Civil War (New York: Cambridge University Press, 2000). Chapel Hill did not receive railroad service until 1882.

${ }^{7}$ W. S. A., "Literary History of North-Carolina," The American Review and Literary Journal for the year 1802, 2 (New York): 375-79; Patrick M. Valentine, "Libraries and Print Culture in Early North Carolina," North Carolina Historical Review [cited hereafter as NCHR] 83 (July 2005): 293-325; and idem, "Useful Books: Community Libraries in Antebellum North Carolina” North Carolina Libraries 64 3/4 (Fall-Winter 2006): 60-69; Haynes McMullen, American Libraries before 1876 (Westport, Ct: Greenwood Press, 2000), 27-28, 104-09.

${ }^{8}$ Louis Round Wilson, "Papers on the U. N. C. Library” (typescript, 1966), North Carolina Collection, Wilson Library, University of North Carolina at Chapel Hill [cited hereafter as NCC], esp. 1:189-217; [Walker Anderson] "Autobiography of Rev. Joseph Caldwell,” (1835/1860; electronic ed., http://docsouth.unc. edu/fpn/caldwell/caldwell.html, 1997), 62-63; Kemp P. Battle, History of the University of North Carolina, 2 vols. (1912; reprint, Spartanburg, SC: Reprint Co., 1974), 1:7-8, 128-29, 294-95, 40411; R. D. W. Connor, A Documentary History of the University of North Carolina, 1776-1799, 2 vols. (Chapel Hill: University of North Carolina Press, 1953), I:83-84, 348-49 (procuring quotation, 388), 449, 457-58; 2:31, 380, 492-93; Sarah McCulloh Lemmon, ed., The Pettigrew Papers, 2 vols. to date (Raleigh: State Department of Archives and History, 1971- ), I:148, 183, 210; Powell, "Development of Libraries in Southern State Universities,” 21. For student textbook expenses, see Catalogue of the Trustees, Faculty and Students of the University of North Carolina, October 1, 1837 (Raleigh: J. Gales and Son, 1837), 13. South Carolina quotation, J[ames] W[arley] Miles, First Annual Report of the Librarian of the College of Charleston (Charleston: Steam Power Press of Walker, Evans and Co., 1857), 4.

${ }^{9}$ Elisha Mitchell to Thomas Ruffin, January 23, 1822, J. G. de Roulhac Hamilton, ed., The Papers of Thomas Ruffin, 4 vols. (Raleigh: Edwards \& Broughton, 1918-1920), I:263. Cf., William Henry Foote, Sketches of North Carolina...(1846; reprint, New Bern: Owen G. Dunn, 1966), 335; John H. Wheeler, Reminiscences and Memoirs of North Carolina and Eminent North Carolinians (Columbus, Ohio: Columbus Printing, 1884), 54 (quotation), 170.

${ }^{10}$ Even then, book acquisition in Virginia remained extremely limited in the absence of regular appropriations. William Couper, One Hundred Years at V. M. I., 4 vols. (Richmond, Va.: Garrett and Massie, 1939), I:81, 95, 295; Bradford Wineman, “J. T. L. Preston and the Origins of the Virginia Military Institute, 183442," Virginia Magazine of History and Biography 114 (2006): 226-261, esp. 253; Harry Clemmons, The University of Virginia Library 1825-1950 (Charlottesville: University of Virginia Library, 1954), 21-25, 28-30; John Luster Brinkley, On This Hill: A Narrative History of Hampden-Sydney College 1704-1994 (Hampden-Sydney: Hampden-Sydney College, 1994): 239-41. ${ }^{11}$ M. L. McVaugh, “Elisha Mitchell's Books and the University of North Carolina Library," Book Mark (University of North Carolina, Wilson Library, 1987, 1990), 55:27-54; 56:31-70; Rogers McVaugh et al, Chapel Hill and Elisha Mitchell the Botanist (Chapel Hill: Botanical Garden Foundation, 1996), 15. ${ }^{12}$ Archibald Henderson, The Campus of the First State University
(Chapel Hill: University of North Carolina Press, 1949), 9799, 147-48; Frances B. Everhart, "The South Carolina College Library,” Journal of Library History 3 (1968): 228. See also R. J. Ashe to Thomas Mitchell, December 28, 1857, and February 23, 1858, in Hamilton, Papers of Thomas Ruffin, 2:575, 585; D. L. Swain to My dear Eleanor [Mrs. Eleanor White Swain], “Epistolary Correspondence of David Lowry Swain,” NCC, 5:25 (August 1826); Clemmons, University of Virginia Library, 22.

${ }^{13}$ Thomas S. Harding, College Literary Societies: Their Contributions to Higher Education in the United States 18151876 (New York: Pageant Press, 1971), 87-117, 179-216; Robert F. Pace, Halls of Honor: College Men in the Old South (Baton Rouge: Louisiana State University Press, 2004); and Laura Francis Parrish, "Books Read by Members of the Philanthropic Society and Their Correlation with Debate Topics, 1828-1832” (master's thesis, University of North Carolina at Chapel Hill, 1979).

${ }^{14}$ Richard B. Creecy to Jos. H. Saunders, William Laurence Saunders papers, October 3, 1832, Duke University, Perkins Library Special Collections [cited hereafter as Duke SC]; and La Mar, “The Libraries of Our Institution," North Carolina University Magazine 3 (February 1854): 28. See also Wheeler, Reminiscences and Memoirs, 339-53; Edgar V. McKnight and Oscar Creech, A History of Chowan College (Murfreesboro: Chowan College, 1964), 141-45; George W. Brooks to Thos. J. Foote, North Carolina Archives, North Carolina Office of Archives and History, Raleigh [cited hereafter as North Carolina Archives], PC 360, 11 October 11, 1855; and Jon L. Wakelyn, "Antebellum College Life and the Relations between Fathers and Sons,” The Web of Southern Social Relations: Women, Family \& Education, ed. Walter J. Fraser, Jr. (Athens: University of Georgia Press, 1985), 319-20.

${ }^{15}$ The Semi-Centennial Catalogue of Davidson College, Davidson, N.C., 1837-1887 (Raleigh: E. M. Uzzell, 1891), 184.

${ }^{16}$ Catalogue of Books belonging to the Dialectic Society, Chapel-Hill, February 1821 (Hillsborough: D. Heartt, 1821); A Catalogue of Books belonging to the Philanthropic Society at Chapel Hill taken $6^{\text {th }}$ May, 1822 (Raleigh: J. Gales \& Son, 1822). See also Catalogue of Books Belonging to the Library of the Dialectic Society at Chapel-Hill, 1827 (Raleigh: J. Gales \& Son, 1827); Catalogue of Books Belonging to the Dialectic Society at Chapel-Hill, May, 1835 (Raleigh: J. Gales \& Son, 1835); Evangeline Burbank Murphy, "The Growth of the Library of the Philanthropic Society at the University of North Carolina, Chapel Hill, 1797-1822" (master's thesis, University of North Carolina at Chapel Hill, 1979); and Jim Ranz, The Printed Book Catalogue in American Libraries: 1723-1900, Association of College and Research Libraries Monographs, 26 (Chicago: American Library Association, 1964).

${ }^{17}$ W. J. Alexander and J[ohn] T[homas] Harry, "Alphabetical catalogue” December 24, 1852, 1,428 titles, Davidson College archives, RG 6/14.2. The author appreciates the help given by Davidson archivist Dr. Jan Blodgett.

${ }^{18}$ William J. Rhees, Manual of Public Libraries, Institutions, and Societies, in the United States ... (Philadelphia: J. B. Lippincott, 1859), 308-309.

${ }^{19}$ Henry Petroski, The Book on the Bookshelf (New York: Alfred A. Knopf, 1999), 8-10, 60-73; Don Heinrich Tolzmann et al., The Memory of Mankind: The Story of Libraries Since the Dawn of History (New Castle, Del.: Oak Knoll Press, 2001), 37, 48.

${ }^{20}$ Stephen Elliott, "Education in Germany," Southern Review 4 (1829): 86-123, esp. 109, 116, and, for libraries, 118-119. That the library situation in Germany was not quite as good as sometimes pictured, indeed sometimes an "artificial chaos," see 
Hugo Kunoff, The Foundations of the German Academic Library (Chicago: American Library Association, 1982); and Jeffrey Garrett, "Redefining Order in the German Library, 1775-1825," Eighteenth-Century Studies 33.1 (1999): 103-23, quotation 113. 21"Handsomely bound" quotation, cited in Erika Lindemann, "The Debating Societies," Documenting the American South electronic file http://docsouth.unc.edu/true/. Other quotations, Charles C. Jewett, Notices of Public Libraries in the United States of America. Printed by order of Congress, as an Appendix to the Fourth Annual Report of the Board of Regents of the Smithsonian Institution (Washington, DC: Senate, 1850), 120. See also Rhees, Manual of Public Libraries, 307-08; Harding, College Literary Societies, 108-09, 114; Southern Historical Collection, University of North Carolina, Wilson Library [cited hereafter as SHC], files 40152 and 40166; and Maurice C. York, "The Dialectic and Philanthropic Societies' Contributions to the Library at the University of North Carolina, 1886-1906," NCHR 59 (1982): 327-53.

${ }^{22}$ See, for instance, Public Libraries in the United States of America: Their History, Condition and Management, Special Report (Washington, DC: Government Printing Office, 1876), I:26 note.

23“Books were more valued than librarians, who might plan and achieve great collections.” O’Brien, Conjectures of Order, 522. Cf., Shiflett, Origins of Academic Librarianship, 36-46.

${ }^{24}$ Connor, Documentary History of the University of North Carolina, 1:351, 401; Dictionary of American Biography, s.v. "Williamson, Hugh"; and Walter A. McDougall, Freedom Just Around the Corner: A New American History 1585-1828 (New York: HarperCollins, 2004): 225-26, 299-302, 564.

${ }^{25}$ Thomas S. Ashe to Thomas Ruffin, January 26, 1834, and W. H. Owen to Thomas Ruffin, April 22, 1842, in Hamilton, Papers of Thomas Ruffin, 2:110, 203-04. Biographical History of North Carolina, s.v., "Saunders, William Laurence". See also Saunders family papers, Duke SC, and SHC 650 and 2658; Wendell W. Smiley, "Library Development in North Carolina before 1930," (typescript, 1930/32; reprint, Greenville: East Carolina University Library, 1971), 24. The $\$ 100$ salary became a regional, indeed national, standard as both V.M.I. and South Carolina College (later the University of South Carolina) are known to have awarded the same amount. Cf., Shiflett, Origins of American Academic Librarianship, 36. See also Wm. H. Owen, "Report on the State of the Library, December 15, 1836," UNC Papers (\#40005), University Archives, University of North Carolina at Chapel Hill, electronic file http://docsouth.unc.edu/unc/unc04-28/ unc04-28.html.

${ }^{26}$ Judge William D. Williamson, "University of North Carolina," North Carolina University Magazine 1 (November 1852): 381 n; Battle, History of the University, 1:408-09, 658, 665 (quotation, 552); Daniel Lindsey Grant, Alumni History of the University of North Carolina (Durham: Christian \& King, 1924, $2^{\text {nd }}$ ed.), 76 and 468; and Hamilton, Papers of Thomas Ruffin, 2:443-46, 530 n. Reverend Forbyce M. Hubbard, with some help from Swain, handled the library during and immediately after the Civil War.

${ }^{27}$ George Washington Paschal, History of Wake Forest College (Wake Forest: Wake Forest College, 1935), 520-33 (quotations, 523-26); Rhees, Manual of Public Libraries, 307-08. Periodicals subscribed to or bought as back issues included North American Review, Edinburgh Review, Christian Review, Southern Literary Messenger, North Carolina Journal of Education, Whig Review, Democratic Review, Aurora, London Quarterly Review, Westminster Review, Blackwood's Magazine, African Repository, and Congressional Globe. A manuscript catalog of 1852-60 listed 3,667 volumes.
28“Normal Department," The Southern Index 1 (May 1850): 27-32; Harding, College Literary Societies, 210-11; William K. Boyd, ed., "Rev. Brantley York on Early Days in Randolph County and Union Institute,” Trinity College Historical Papers 8 (1908); John Franklin Crowell, Personal Recollections of Trinity College, North Carolina, 1887-1894 (Durham: Duke University Press, 1939), 38; Nora Campbell Chaffin, Trinity College, 1839-1892: The Beginnings of Duke University (Durham: Duke University Press, 1950), esp. 71-72, 126-27, 210, 242; and Joseph Penn Breedlove, "Reminiscences on the Early History of Duke University Library,” Library Notes, the Friends of Duke University Library 17 (December 1946): 1-3.

${ }^{29}$ [Chalmers Davison?] "History of the Davidson College Library," 1974 typescript, Davidson College archives; Mary D. Beaty, A History of Davidson College (Davidson: Briarpatch Press, 1988), 65 (quotations, 76, 49, 77 n). Professors supervising the library were paid \$50 a year before the Civil War. Smiley, "Development of Libraries,"40. A British librarian likewise complained in 1903 that British libraries were "clogged with [the] useless lumber" of donated books. Chris Baggs, “'Donations are ... earnestly invited”: Stock Donations in the early History of the British Public Library - Acts of Philanthropy or Shelf Clearing?” Mäzenatentum für Bibliotehken / Philantropy for Libraries [sic], eds. Peter Vodosek, Alistair Black, Peter Hoare (Wiesbaden: Harrassowitz, 2004), quotation 151.

${ }^{30}$ Record of Minutes of the Eumenian Society of Davidson College, May 9, 1859, Davidson College archives. Battle, History of the University, 1:406 (efficacious quotation). See also The SemiCentennial Catalogue of Davidson College, 184; Beaty, History of Davidson College, 47 and 48 n. For Davidson's wealth, see Dr. Fishborne, "Reminiscences of the College, 1837-1859" in North Carolina Archives, D. H. Hill, Jr., Papers, Private Collections, 94.6:17; H. H. Banks, "Davidson College," The South Atlantic 1 (March 1878): 381-90, esp. 385; Chalmers G. Davidson, “Independent Mecklenburg,” NCHR 46 (Spring 1969): 127.

${ }^{31}$ Wheeler, Reminiscences and Memoirs, 222-23; Paschal, History of Wake Forest College, 529, 623. James Wallis, The Bible Defended; being an Investigation of the Misrepresentations and Falsehoods of Thomas Paine's Age of Reason (Halifax, NC: Abraham Hodge, 1797), was one of the first sizeable works printed in North Carolina. See also Avery O. Craven, The Growth of Southern Nationalism, 1848-1861 (Baton Rouge: Louisiana State University Press, 1953); Michael O’Brien, Re-Thinking the South: Essays in Intellectual History (Athens: University of Georgia Press, 1993), 1-56; and Bertram Wyatt-Brown, The Shaping of Southern Culture: Honor, Grace, and War, 1760s-1890s (Chapel Hill: University of North Carolina Press, 2001).

${ }^{32} \mathrm{On}$ the importance of encyclopedias, see Daniel R. Headrick, When Information Came of Age: Technologies of Knowledge in the Age of Reason and Revolution, 1700-1850 (New York: Oxford University Press, 2000), 149-66.

${ }^{33} \mathrm{~J}$. Kelly Turner and Jno. L. Bridgers, Jr., History of Edgecombe County North Carolina (Raleigh: Edwards \& Broughton, 1920), 361. On the slow introduction of women as workers in libraries see Barbara A. Mitchell, “'A Beginning Is Made’: The New Card Catalogue of the Harvard College Library and the Female Labor Force, 1856-1877," Harvard Library Bulletin 14/3 (Fall 2003): 1132; and Dee Garrison, Apostles of Culture: The Public Librarian and American Society, 1876-1920 (1979; Madison: University of Wisconsin Press, 2003).

${ }^{34}$ Lucy Leinbach Wenhold, "The Salem Boarding School Between 1802 and 1822,” NCHR 27 (January 1950): 38, 43; Smiley, "Development of Libraries," 43; Rhees, Manual of Public 
Libraries, 310; Francis Griffin, Less Time for Meddling: A History of Salem Academy and College 1772-1866 (Winston-Salem: John F. Blair, 1979), 98-103; Patrick M. Valentine, "School Libraries in antebellum North Carolina (in preparation).

${ }^{35}$ One teacher cum editor stated "All sectarian schools 'deserve contempt'." Southern Index 1 (March 1850): 11. See also Donald G. Tewksbury, The Founding of American Colleges and Universities Before the Civil War (1932, reprint; n.p.: Archon Books, 1965), 28; Daniel J. Boorstin, The Americans, 3 vols. (New York: Vintage, 1958-1974), 2:152-61; Michael T. Malone, “The Episcopal School of North Carolina, 1832-1842," NCHR 49 (April 1972): 178-94; and Valentine, Rise of a Southern Town, 20.

${ }^{36}$ The following have little or no mention of a library during this period: Mildred Morse McEwan, Queens College Yesterday and Today (Charlotte: Queens College Alumnae Association, 1980), 16-54; Life at Saint Mary's, Katherine Batts Salley, ed. (Chapel Hill: University of North Carolina Press, 1942); "Greensboro Female College,” Southern Index 1 (May 1850): 23-25. See also Guion Griffis Johnson, Ante-Bellum North Carolina: A Social History (Chapel Hill: University of North Carolina Press, 1937), 307.

${ }^{37}$ Rhees, Manual of Public Libraries, 310, quotation 626-27.

${ }^{38}$ Patricia Allen Rogers, "A History of the Louisburg College Library, 1787-1965” (Master's thesis, University of North Carolina at Chapel Hill, 1982), 1-11.

${ }^{39}$ Catalogue of the Officers and Students of Lenoir Collegiate Institute male and female 1857-8 (Kinston: American Advocate Office, 1858), does not mention any library. Lenoir Collegiate Institute, founded by Methodists in 1855, was meant as a preparatory school for Normal [i.e., Trinity-Duke] and Greensboro Female College. Similarly, see Davenport Female College, Catalogue of Paintings, April 21, 1861 (n.p., n.d.): the painting collection was significant enough to catalog but not its books. Methodists opened Davenport in Lenoir (Caldwell County, across the state from Lenoir Collegiate Institute in Lenoir County), as a rival to the Presbyterian female college at Statesville. Davenport was disbanded "at the approach of the Federal Army ... not knowing what license might be allowed a reckless soldiery." W. M. Robey, Centennial of Methodism in North Carolina... (Raleigh: J. Nichols, 1976), 193-201, quotation 201. See also Thomas Hall Wetmore, "The Literary and Cultural Development of Ante-Bellum Wilmington” (Master's thesis, Duke University, 1940), 157-60. Tewksbury, Founding of American Colleges and Universities, 17, found an 81 percent failure rate in college formation.

${ }^{40}$ Peace College, "founded" in 1857, did not open until after the Civil War.

${ }^{41} \mathrm{O}$ 'Brien, Conjectures of Order, contains over 1,200 pages of text. See also Michael Thomas Smith, A Traitor and a Scoundrel: Benjamin Hedrick and the Cost of Dissent (Newark: University of Delaware, 2003); and David Brown, Southern Outcast: Hinton Rowan Helper and 'The Impending Crisis of the South' (Baton Rouge: Louisiana State University Press, 2006).

${ }^{42}$ Shiflett, Origins of American Academic Librarianship, 26, 33; Kenneth E. Carpenter, The First 350 Years of the Harvard University Library (Cambridge: Harvard University Press, 1986), 46.

${ }^{43} \mathrm{O}$ 'Brien, Conjectures of Order, 491. For comparisons of southern library size with northern, see Louis Round Wilson, The Geography of Reading: A study of the distribution and status of libraries in the United States (Chicago: University of Chicago Press, 1938); and Haynes McMullen, American Libraries before
1876 (Westport, Ct: Greenwood Press, 2000). McMullen’s notes are available at http://www.princeton.edu/ davpro/databases/ index.html.

${ }^{44} \mathrm{~A}$ recent examination of Southern cultural nationalism is Michael Thomas Bernath, "Confederate Minds: The Struggle for Intellectual Independence in the Civil War South” (Ph.D. dissertation, Harvard University, 2005).

${ }^{45}$ The Seventh Census of the United States: 1850 (Washington: Robert Armstrong, 1853); Jewett, Appendix to the Report of the Board of Regents of the Smithsonian Institution, 190-91; Rhees, Manual of Public Libraries, xxvi-xxvii, 626-27; Population of the United States in 1860 (Washington: Government Printing Office, 1864); University of Virginia, Geospatial and Statistical Data Center. United States Historical Census Data Browser: http:// fisher.lib.virginia.edu/census/. Florida is not recorded as having any college libraries at this time.

${ }^{46}$ Alban Daumas, "Des bibliothèques des facultés aux bibliothèques universitaires," Histoire des bibliothèques françaises (Paris: Promodis, 1991), III, 417-435; and Peter Freshwater, "Books and Universities," The Cambridge History of Libraries in Britain and Ireland (New York: Cambridge University Press, 2006), III, 345370.

${ }^{47}$ For equipment, see, Beaty, History of Davidson College, 77; Paschal, History of Wake Forest College, 523-25, or, in general, Adam Arenson, "Libraries in Public before the Age of Public Libraries: Interpreting the Furnishings and Design of Athenaeums and Other 'Social Libraries'," The Library as Place: History, community, and culture, eds. John E. Buschman and Gloria J. Leckie (Westport, Ct: Libraries Unlimited, 2007), 41-60. For contemporary assessments of library services, see Reuben A. Guild, The Librarian's Manual; a Treatise on Bibliography... to which are added, Sketches of Publick Libraries (1858; reprint, Detroit: Grand River Books, 1971); American Social Science Association, Free Public Libraries: Suggestions on Their Foundation and Administration ... (Cambridge, Mass.: Riverside Press, 1871); and George Burwell Utley, The Librarians' Conference of 1853, a chapter in American history (Chicago: American Library Association, 1951).

${ }^{48} \mathrm{La}$ Mar, "Libraries of Our Institution," 66.

${ }^{49}$ Harvey J. Graff, "Literacy, Libraries, Lives: New Social and Cultural Histories,” in Donald G. Davis, Jr., ed., Reading \& Libraries (Austin: University of Texas at Austin, 1991), 26, 32. See also Robert Darnton, The Kiss of Lamourette (New York: Norton, 1990), 107-35 and 154-8; Lawrence W. Levine, The Unpredictable Past: Explorations in American Cultural History (New York: Oxford University Press, 1993), 3-13; Roger Chartier, The Order of Books, trans. Lydia G. Cochrane (Stanford: Stanford University Press, 1994), 1-23; Kenneth E. Carpenter, Readers \& Libraries: Toward a History of Libraries and Culture in America (Washington, D.C.: Library of Congress, 1996), 7-8; and Anne C. Rose, Voices of the Marketplace: American Thought and Culture 1830-1860 (Lanham, Md: Rowman and Littlefield, 2004 ed.), 180-82.

${ }^{50}$ Jack P. Green, "Early Modern Southeastern North America and the Broader Atlantic and American Worlds," Journal of Southern History LXXIII/3 (August 2007): 525.

${ }^{51}$ See Daniel Wickberg, "What Is the History of Sensibilities? On Cultural Histories, Old and New," American Historical Review 112/3 (June 2007): 661-684. 